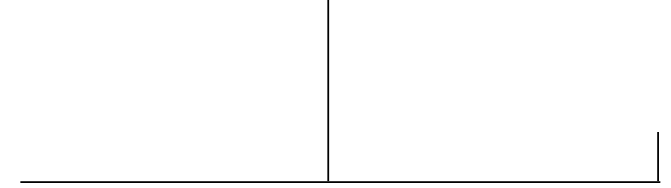

Rev. Latinoam. Psicopat. Fund., São Paulo, v. 11, n. 2, p. 339-342, junho 2008

Pedofilia - Um estudo psicanalítico

Fani Hisgail

São Paulo: Iluminuras, 2007, 124 págs.

\title{
Acerca da necessária coragem para levar à cultura reflexões sobre seu mais persistente e polêmico tabu.
}

Clóvis Pereira

As formas de sobreviver ao trauma sexual podem deixar enormes seqüelas, por exemplo, fechando-se em si mesma e com vergonha de revelar o que se passou na cena do abuso. A resistência e a dificuldade de dizer o que aconteceu têm o propósito de proteger o eu do risco de desintegração, sendo este testemunha passiva do ato pedófilo.

(Hisgail, p. 42)

Quando em março de 2002 as mídias apresentaram para o horror geral da nação - imagens editadas do hebeatra [pois sim, hebeatra: o "especialista" em adolescentes, termo desconhecido então do conjunto da cultura; pensávamos que só os havia pediatras] dr. Eugênio Chipkevich, em uníssono 
jornalistas, polícias, pais e doutores da lei pediram dele o pescoço. "De médico, passou a ser 'monstro' e 'maníaco sexual', aproximando a opinião pública, mais uma vez, ao tema da pedofilia. Explorou-se ao máximo o assunto, de modo que as designações pejorativas estampavam reportagens com informações dúbias e ambíguas sobre as causas da pedofilia" (p. 49).

Aos 48 anos de idade, o especialista em jovens foi condenado a 124 anos de reclusão. Em sua defesa declarou à mídia, num determinado momento, que não fizera nada por mal, posto que na Grécia isso era normal e fazia parte do processo de educação dado pelos preceptores aos hefebos.

Pois sim, os gregos não tinham nem as elevadas doses de Dormonid, tampouco a sintomática câmera de filmagens que resultariam em provas de condenação criadas pelo próprio doutor. Apenas o conceito freudiano de supereu fornece as pistas para compreender por que ele filmava e, ato contínuo, descartava as fitas onde pudessem eventualmente ser encontradas.

Todavia, em que pese a polêmica, ele estava certo. Entre os gregos nosso crime era simples etapa do processo pedagógico. O bem-nascido dr. Eu-gênio parecia convencido de que sua transgressão era um privilégio concedido às vítimas. Meninos de classe média alta, também eu-genicamente nascidos.

Por certo, faltou à formação do eminente especialista em corpos jovens algumas aulas de história básica. Aquelas em que o professor apresenta uma cronologia que evidencia os 2.500 anos que nos separam do século de Péricles, auge da pedagogia ateniense. Ops, Chipkevich é o médico ideal para meus filhos, só está na época errada.

A mesma lógica poderia levar Fernandinho Beira-Mar a defender-se das acusações de narcotráfico lembrando que, até 1917, nos EUA e na Europa, a cocaína era vendida em quaisquer farmácias com a qualidade garantida por marcas como Laboratórios Merck ou Parke, Davis \& Co. A bula, assinada por Sigmund Freud, colocaria Fernandinho Beira-Mar na condição de benfeitor da sociedade; apenas em uma época imprópria.

A questão é de tempo. Não mais. Os professores de história são, então, os verdadeiros criminosos. Visto que não levaram aos seus pupilos - Fernando e Eugênio - a informação de que o tempo não é um detalhe, mas o fundamento das culturas. Apenas aos idiotas é facultado ignorar dele tempo a relevância.

Não somos gregos, ainda que nossos vocábulos, mitos e nomes venham de lá.

Acipitrídeos são as aves de uma família cujas características são os bicos enormes e fortes, os pescoços pelados e a alimentação feita a partir de animais mortos. Ainda que façam a higiene do meio ambiente, são abutres. Neste caso, também alguns jornalistas. Preocupados em esfolar o corpo, as mídias perderam 
a oportunidade de levar qualquer reflexão mais intensa ao populacho sedento. Afinal, Chipkevich não era um pária social, lúmpen. Antes, era um nome de referência na medicina. Um profissional caro, especializado... confiável.

Tomando sua imagem como a um monstro, os jornalistas subtraíram da população a possibilidade de implicar-se na história da pedofilia. De compreender que pedófilos são pais, professores, médicos, padres, pastores. Pessoas comuns, "de bem", enfim.

Uma vez que o problema é posto no outro monstruoso, não temos nada a ver com ele. No tocante à pedofilia, esta prática na imprensa tem feito desserviços enormes.

Está aí o mérito desse livro que nos chega a partir de uma pesquisa de doutorado da psicanalista Fani Hisgail. Escapando tanto aos elitismos acadêmicos quanto ao hermetismo próprio a alguns clínicos formados no lacanismo, Hisgail coloca em cena o problema mais polêmico e recalcado na cultura pós-moderna.

Sem prescindir às referências legais e sociológicas, Hisgail expõe alguns casos sintomáticos à luz dos conceitos psicanalíticos. Internet, romances, filmes, casos policiais, povoam seu livro causando um necessário mal-estar naqueles que sempre têm para si que o problema é uma patologia localizada em alguns sujeitos. Poucos sujeitos que poderiam ser excretados pela agressividade oportunista da imprensa marrom ou pela acefalia policialesca. "Tropas de elite" purgam nossa própria agressividade. Achando sempre o mal no outro. O inferno é o outro, fazem crer. Hisgail lembra que, no espelho lacaniano, nós próprios somos o efeito do Outro. A pedofilia está na cultura, não no gene isolável duma parcela dos indivíduos. De nada vale chutar o doutor se não refletirmos sobre as causas primeiras que levam ao problema dessa perversão, onde a alteridade do infans é negada, tornando-o um pequeno objeto.

Devemos receber esta produção com a mesma reverência dispensada a autores como a professora Mary Del Priori [pesquisadora da História da USP e especialista em temas ligados à história da mulher e da infância] ou como o antropólogo Luiz Mott [cujos textos relativos à pedofilia e à homossexualidade no Brasil suscitam positivas polêmicas em diversas mídias].

Hisgail acrescenta à sua pesquisa acadêmica o traço sensível de sua experiência clínica e o resultado não é apenas prazeroso à leitura, mas antes necessário à cultura, aos sujeitos ligados ao tema da pedofilia. Professores, advogados, assistentes sociais, psicólogos e pais têm agora mais uma fonte consistente para pensarem estas questões a partir da angústia sentida, e não simbolizada, por crianças que silenciosamente suportam esta redução de suas potencialidades sociais à condição de objeto do desejo. Do desejo perverso vindo desses sujeitos que as crianças aprenderam a respeitar e admirar. 
Esta admiração leva, por vezes, como nos ensina Hisgail, o pedófilo a concluir que está fazendo um bem à criança. Que é uma relação consensual. Ou, ainda, que é algo que todos devem fazer. Como - eles dizem - os gregos faziam.

\section{Clóvis Pereira}

Psicanalista; mestre em Semiótica pela Pontifícia Universidade Católica de São Paulo - PUCSP (São Paulo, SP, Brasil); doutorando em História Social no Depto. de História da Faculdade de Filosofia, Ciências e Letras da Universidade de São Paulo - USP (São Paulo, SP, Brasil); membro do Laboratório de Estudos sobre a Intolerância, da Universidade de São Paulo - USP; professor do Curso de Especialização em Semiótica Psicanalítica da Pontifícia Universidade Católica de São Paulo - PUC-SP.

Rua Miquelina Tulio de Christillo, 94 - Jd. Santa Rosa

06755-025 Taboão da Serra, SP

Fones: (11) 4787-9767 / 8106-8433

e-mail: clovisgaia@hotmail.com 